\title{
Stability of enzyme complex solid-state fermentation subjected to the processing of pelleted diet and storage time at different temperatures
}

\author{
Guilherme de Souza Moura1, Eduardo Arruda Teixeira Lanna', Juarez Lopes Donzele', \\ Daniel Luciano Falkoski², Sebastião Tavares de Rezende ${ }^{2}$, Maria Goreti de Almeida Oliveira ${ }^{2}$, \\ Luiz Fernando Teixeira Albino ${ }^{1}$
}

\author{
${ }^{1}$ Universidade Federal de Viçosa, Departamento de Zootecnia, Viçosa, MG, Brazil. \\ ${ }^{2}$ Universidade Federal de Viçosa, Instituto de Biotecnologia Aplicada à Agropecuária, Viçosa, MG, Brazil.
}

\begin{abstract}
The effects of processing of pelleted diets and their storage time on the stability of the enzyme complex SSF (solid-state fermentation) were evaluated. Two diets were formulated with the same nutritional composition, differing only in the Schizochytrium sp. levels $\left(0 \mathrm{~g} \mathrm{~kg}^{-1}\right.$ and $\left.50 \mathrm{~g} \mathrm{~kg}^{-1}\right)$. The samples were collected during the following processing steps: mixing, then pelleting, and then oven. To evaluate the storage time, the diet ready after drying was considered as day 1 . On this day, two samples were obtained, being one kept in a room with ambient temperature of $25^{\circ} \mathrm{C}$ and another stored in freezer at $-18^{\circ} \mathrm{C}$. At 15, 30, 45, and 60 days, sub-samples were taken. All samples from the processing step and storage time were sent to the laboratory and the following enzyme activities were measured: $\alpha$-galactosidase, endoglucanase (carboxy-methyl-cellulase), xylanase, sucrase, amylase, lipase, and trypsin. There were no significant differences between the mixture and post-oven phase, except for the activity of $\alpha$-galactosidase, lipase, and sucrase. For the storage temperature of $25{ }^{\circ} \mathrm{C}$, no effect was observed for the activities of endoglucanase, sucrase, xylanase, amylase, and trypsin between the first (after oven) and the 60th day of the trial. As for the storage temperature of $-18{ }^{\circ} \mathrm{C}$, no difference was observed, except for the activities of endoglucanase and xylanase between the first and last day. Comparing the two types of storage $\left(25^{\circ} \mathrm{C}\right.$ and $\left.-18{ }^{\circ} \mathrm{C}\right)$, there was difference only for the activity of galactosidase and trypsin at 60 days. The enzymes of the enzyme complex SSF studied remain stable during the processing of pelleted diet at $55^{\circ} \mathrm{C}$, maintaining activity for at least 60 days when stored at temperatures up to $25^{\circ} \mathrm{C}$.
\end{abstract}

Key Words: animal nutrition, feed additive, fermentation, microbial additive

\section{Introduction}

The use of enzyme complex in animal feeding improves the utilization of nutrients that would otherwise be unavailable (Leite et al., 2011), reflecting positively on the performance and reducing the pollution load of excreta (Opalinski et al., 2010). However, the inclusion of enzymes in formulations should be made carefully, because this additive may lose their biological activity during pelleting process, which involves high temperatures, moisture, and pressure.

The enzymes used in animal feed should resist and maintain considerable activity after the manufacturing and digestion processes to justify their inclusion in the diets (Dias et al., 2002; Shah and Madamwar, 2005). The factors

Received November 5, 2015 and accepted September 28, 2016.

Corresponding author: mouraguilherme@yahoo.com.br

http://dx.doi.org/10.1590/S1806-92902016001200001

Copyright () 2016 Sociedade Brasileira de Zootecnia. This is an Open Access article distributed under the terms of the Creative Commons Attribution License (http://creativecommons.org/licenses/by/4.0/), which permits unrestricted use, distribution, and reproduction in any medium, provided the original work is properly cited. that may influence their stability, among others, are: the origin (organism), the type of enzyme, the diet composition, the processing conditions (temperature, pressure, and moisture), the storage, the conditions during the digestion process, and the action of endogenous enzymes (Ramos et al., 2012).

Today, most enzymes used in animal diets are produced by fungi; however, they can be readily denatured at temperatures above $60{ }^{\circ} \mathrm{C}$. The enzyme stability is superior when incorporated with other ingredients of the formulation, which reduces the possibility of inactivation (Francesch et al., 1995). Therefore, an ideal enzyme must be able to withstand temperatures above $70{ }^{\circ} \mathrm{C}$, since the processing of pelleted and extruded diets uses temperatures higher than this (Finnfeeds International, 1991). Moreover, enzymes must maintain their biological activity over time. According to Cowan (1993), the enzymes can be stable for more than three months at $25^{\circ} \mathrm{C}$ when blended with other ingredients.

Considering the options of enzyme complexes, the complex solid-state fermentation (SSF) seems to stand out due to its qualitative features. Besides being naturally produced by fungi of the genus Aspergillus on solid matrix (Vats and Banerjee, 2004), SSF may have dozens of enzymes that work in synergy (carbohydrases, proteases, and others), 
providing more nutrients, which may improve performance of animals (Moura et al., 2015). However, studies on the stability of enzymes present in this complex should be performed, because this is subjected to various physical and chemical factors of the diet during the processing, storage, and digestive processes, which can reduce or inactivate its catalytic activity.

The effects of processing and storage time on the stability of enzymes of the enzyme complex SSF in pelleted diets for animals were evaluated.

\section{Material and Methods}

The trial was conducted in Viçosa, Minas Gerais, Brazil.

Two isonutritive diets were formulated containing $360 \mathrm{~g} \mathrm{~kg}^{-1}$ of crude protein (CP) and $2,700 \mathrm{kcal} \mathrm{kg}^{-1}$ of digestible energy (DE) in the diet (Table 1). This diet was formulated according to the requirements recommended for omnivore fish, but the type of processing and the enzyme activity can be applied to any animal species. The control diet was formulated without SSF and $50 \mathrm{~g} \mathrm{~kg}^{-1}$ of enzyme complex was added to the other experimental diet.

Table 1 - Composition of experimental diets ${ }^{1}$

\begin{tabular}{lcc}
\hline \multirow{2}{*}{ Ingredient $\left(\mathrm{g} \mathrm{kg}^{-1}\right)$} & \multicolumn{2}{c}{ Treatment } \\
\cline { 2 - 3 } & No SSF & With SSF \\
\hline Soybean meal & 504.7 & 504.7 \\
Ground corn & 163.4 & 163.4 \\
Gluten 60 & 181.3 & 181.3 \\
Wheat meal & 53.7 & 53.7 \\
Soybean oil & 10.2 & 10.2 \\
Inert (Caulin) & 50.0 & - \\
SSF & - & 50.0 \\
Dicalcium phosphate & 26.9 & 26.9 \\
Vitamin and mineral mix & 5.0 & 5.0 \\
Vitamin C & 0.5 & 0.5 \\
Salt & 0.4 & 0.4 \\
Antioxidant $\left(\mathrm{BHT}^{3}\right)$ & 0.2 & 0.2 \\
Total & 1000 & 1000 \\
Calculated composition & & \\
Crude protein $\left(\mathrm{g} \mathrm{kg}^{-1}\right)$ & 360.0 & 360.0 \\
Digestible energy $\left(\mathrm{kcal} \mathrm{kg}^{-1}\right)$ & 2700 & 2700 \\
Crude fiber $\left(\mathrm{g} \mathrm{kg}^{-1}\right)$ & 36.9 & 36.9 \\
Total calcium $\left(\mathrm{g} \mathrm{kg}^{-1}\right)$ & 8.1 & 8.1 \\
Total phosphorus $\left(\mathrm{g} \mathrm{kg}^{-1}\right)$ & 9.3 & 9.3 \\
\hline
\end{tabular}

${ }^{1}$ Calculated composition according to Rostagno et al., 2011.

${ }^{2}$ Allzyme SSF, Alltech Inc.

${ }^{3}$ Composition per kg of product: vitamin A, 1,200,000 IU; vitamin D3, 200,000 IU; vitamin E, 1,200 mg; vitamin K3, 2,400 mg; vitamin B1, 4,800 mg; vitamin B2, 4,800 mg; vitamin B6, 4,800 mg; vitamin B12, 4,800 mg; vitamin C, $48 \mathrm{~g}$; folic acid, $1200 \mathrm{mg}$; pantothenic acid, 12,000 mg; biotin, $48 \mathrm{mg}$; choline chloride, $108 \mathrm{~g}$; niacin, 24,000 mg; Fe, 50,000 mg; Cu, 3,000 mg; Mn, 20,000 mg; Zn, 30,000 mg; I, $100 \mathrm{mg}$; Co, $10 \mathrm{mg}$; Se, $100 \mathrm{mg}$.

${ }^{4}$ Vitamin C: calcic salt, 2-monophosphate of ascorbic acid, $42 \%$ active principle.
The ingredients were weighed and placed in a plastic bag for mixing. These bags were shaken for $5 \mathrm{~min}$, providing a homogeneous mixture of ingredients. This mixture was placed in a bowl and water (at $55{ }^{\circ} \mathrm{C}$ ) was added until the dough reached the point alloy. Soon after, the pellet machine received this dough and the wet pellets were produced. These pellets remained in forced ventilation oven at $55{ }^{\circ} \mathrm{C}$ for $14 \mathrm{~h}$, which promoted its drying.

The trial was started at the moment of the processing of experimental diets and the samples were collected during the following steps: mixing, then pelleting, and then drying in an oven at $55^{\circ} \mathrm{C}$ for $14 \mathrm{~h}$. To evaluate the storage time, the diet ready after drying was regarded as day 1 . On this day, two samples were taken, one kept at room temperature at $25{ }^{\circ} \mathrm{C}$ and one kept in a freezer at $-18{ }^{\circ} \mathrm{C}$.

At 15, 30, 45, and 60 days, sub-samples were taken to the two kinds of storage. All samples, the processing steps, and storage time were submitted to the laboratory and the activity of the following enzymes were measured: $\alpha$-galactosidase, endoglucanase (carboxymethyl cellulase), xylanase, sucrase (invertase), $\alpha$-amylase, lipase, and Trypsin.

To assess $\alpha$-galactosidase, endoglucanase, xylanase, and sucrase, $200 \mathrm{mg}$ of each sample of feed were macerated in $10 \mathrm{~mL}$ of buffer solution of $100 \mathrm{mM}$ sodium acetate. This mixture was centrifuged at 13,000 rpm for $2 \mathrm{~min}$ and the supernatant (extract) was removed and stored in a freezer at $-18{ }^{\circ} \mathrm{C}$ for enzyme analysis.

The activity of $\alpha$-galactosidase was determined by measuring the amount of reducing sugar produced through the use of dinitrosalicylic acid (DNS) reagent according to Miller (1956). The reaction mixture was composed of $325 \mu \mathrm{L}$ sodium acetate buffer $(100 \mathrm{mM}, \mathrm{pH} 5), 125 \mu \mathrm{L}$ of a solution of $10 \mathrm{mM}$ sucrose, and $50 \mu \mathrm{L}$ of enzyme extract. The trial was conducted in a water bath for $15 \mathrm{~min}$ at $40^{\circ} \mathrm{C}$. To stop the reaction, $1 \mathrm{~mL}$ of DNS reagent was added, followed by immersion of the test tube in boiling water bath for $5 \mathrm{~min}$. The spectrophotometric measurements were taken at $540 \mathrm{~nm}$ and absorbance values converted into $\mu$ moles of reducing sugar, using a standard curve constructed from glucose amounts ranging from 0.2 to $2 \mu$ moles.

For endoglucanase assay, $30 \mu \mathrm{L}$ of the enzyme solution was mixed with $400 \mu \mathrm{L}$ of carboxymethyl cellulose $(0.625 \% \mathrm{w} / \mathrm{v})$ and diluted in $70 \mu \mathrm{L}$ of sodium acetate buffer $(100 \mathrm{mM}, \mathrm{pH} 5)$. This solution was placed in a water bath at $50{ }^{\circ} \mathrm{C}$ for $30 \mathrm{~min}$ and the reaction stalled according to Miller (1956), using $500 \mu \mathrm{L}$ of DNS and boiling water bath for $5 \mathrm{~min}$. Afterwards, the spectrophotometric measurements were made at $540 \mathrm{~nm}$. 
The xylanase activity was determined using $70 \mu \mathrm{L}$ sodium acetate buffer (100 mM, pH 5), $30 \mu \mathrm{L}$ of enzyme extract, and $400 \mu \mathrm{L}$ of birch wood xylan solution $(1.25 \%$ $\mathrm{w} / \mathrm{v})$. The reaction was conducted for $20 \mathrm{~min}$ at $40{ }^{\circ} \mathrm{C}$ and paralyzed with $500 \mu \mathrm{L}$ of DNS. This solution was incubated in boiling water bath for $5 \mathrm{~min}$ for color development. The activity was determined at $540 \mathrm{~nm}$ using a standard glucose curve.

For sucrase activity, $15 \mu \mathrm{L}$ of enzyme extract was added to $125 \mu \mathrm{L}$ of sucrase solution ( $2 \mathrm{~g}$ sucrose for analysis in $50 \mathrm{~mL}$ of sodium acetate buffer, $100 \mathrm{mM}$, $\mathrm{pH}$ 5) and $360 \mu \mathrm{L}$ sodium acetate buffer solution (100 mM, $\mathrm{pH}$ 5). This solution was immediately placed in a water bath at $30{ }^{\circ} \mathrm{C}$ for $30 \mathrm{~min}$ and the reaction terminated with $500 \mu \mathrm{L}$ DNS. Subsequently, the sample was taken to a bath in boiling water for $5 \mathrm{~min}$ and cooled in ambient temperature. Then, the activities were read in a spectrophotometer at $540 \mathrm{~nm}$.

For $\alpha$-amylase, trypsin, and lipase, $0.5 \mathrm{~g}$ of diet sample was macerated with $10 \mathrm{~mL}$ of $0.1 \mathrm{M}$ Tris- $\mathrm{HCl}$ buffer solution. This material was placed into polyethylene tubes and centrifuged at $12,000 \mathrm{rpm}$ for $10 \mathrm{~min}$. Thus, the supernatant was removed for determination of enzyme activity.

The $\alpha$-amylase activity was based in the starch hydrolysis with release of dextrin and maltose molecules. By adding iodine, unhydrolysed starch acquires blue color. The amylase activity is inversely proportional to the intensity of blue color and is calculated by comparison with a control substrate. The $\alpha$-amylase activity was determined in spectrophotometer at $660 \mathrm{~nm}$ wavelength, using the amylase of Bioclin colorimetric kit according to Caraway (1959).

The trypsin activity was obtained using N-BenzoylD-p-nitroanilide L-arginine (D, L-BApNA) as substrate according to the method described by Erlanger et al. (1961). Ten $\mu \mathrm{L}$ of enzyme extract was added, and immediately, the initial velocity was obtained by forming the p-nitroalinine. This reaction was determined in absorbance at $410 \mathrm{~nm}$ as a function of time. For calculations, the molar extinction coefficient of $8,800 \mathrm{M}^{-1} \mathrm{~cm}^{-1}$ was used for the product.

For lipase activity, we used the Bioclin kit with the modified methodology of Cherry (1932). This methodology evaluated the lipase action present in the extract of the diet on a glycerol ester, releasing a chromogen, which was quantitatively determined in a spectrophotometer at $410 \mathrm{~nm}$. The intensity of color formed was proportional to lipase activity.

All enzyme analyzes were performed with three replicates in duplicate. For statistical analysis we used the SAS software (Statistical Analysis System, version 9.0).
The means were compared by SNK (Student Newman Kells) test at 0.05 to the assessment of processing and storage time. Through the $\mathrm{F}$ test at 0.05 we evaluated the means of two different forms of storage $\left(25^{\circ} \mathrm{C}\right.$ and $\left.-18^{\circ} \mathrm{C}\right)$. The results of the activities were also measured in terms of relative enzymatic activity, considering the initial phase of each time at $100 \%$.

\section{Results and Discussion}

Enzyme activities were not observed in all the samples of the control treatment. Thus, only the means of enzyme activities of the treatment with SSF subjected to the processing and storage time at different temperatures were demonstrated.

Over the processing (Table 2), the mixture was subjected to the pelletizing temperature of $55^{\circ} \mathrm{C}$ and $14 \mathrm{~h}$ in forced-ventilation oven at the same temperature. In general, the enzyme complex SSF was stable in relation to chemical and physical adversities of the trial. There were no observed differences $(\mathrm{P}>0.05)$ between the mixture and the post-oven step for activities of endoglucanase, xylanase, amylase, and trypsin. However, the $\alpha$-galactosidase activity was significantly reduced $(\mathrm{P}<0.05)$ by $13.2 \%$, unlike the sucrase and lipase activities, which increased $(\mathrm{P}<0.05)$ in $8.3 \%$ and $5.5 \%$, respectively.

The activity results of the enzymes involved in this study were consistent with Spring et al. (1996), who tested the effect of the temperature of the pellet $\left(60^{\circ} \mathrm{C}\right.$ to $\left.100{ }^{\circ} \mathrm{C}\right)$ on the activity of cellulase, amylase, and pentosanase in diets with wheat and barley. The authors concluded that the enzyme activity was maintained at a pellet temperature

Table 2 - Enzyme activity from enzyme complex SSF in diets for animals during the processing

\begin{tabular}{|c|c|c|c|c|}
\hline \multirow{2}{*}{ Enzyme } & \multicolumn{3}{|c|}{ Sampling } & \multirow{2}{*}{ CV $(\%)$} \\
\hline & Mix & Pelleting & Post oven & \\
\hline Galactosidase $\left(\mathrm{U} \mathrm{g}^{-1}\right)$ & $12.69 \mathrm{a}$ & $12.42 \mathrm{a}$ & $11.02 \mathrm{~b}$ & \multirow[t]{2}{*}{4.165} \\
\hline Relative activity (\%) & 100 & 97.9 & 86.8 & \\
\hline Endoglucanase $\left(\mathrm{U} \mathrm{g}^{-1}\right)$ & 270.4 & 330.7 & 274.9 & \multirow[t]{2}{*}{5.514} \\
\hline Relative activity (\%) & 100 & 122.3 & 101.7 & \\
\hline Sacarase $\left(\mathrm{U} \mathrm{g}^{-1}\right)$ & $91.3 \mathrm{c}$ & $109.5 \mathrm{a}$ & $98.9 \mathrm{~b}$ & \multirow[t]{2}{*}{3.355} \\
\hline Relative activity (\%) & 100 & 120.0 & 108.3 & \\
\hline Xylanase $\left(\mathrm{U} \mathrm{g}^{-1}\right)$ & $358.3 \mathrm{~b}$ & $486.1 \mathrm{a}$ & $360.7 \mathrm{~b}$ & \multirow[t]{2}{*}{4.978} \\
\hline Relative activity (\%) & 100 & 135.7 & 102.4 & \\
\hline Amylase $\left(\mathrm{AU} \mathrm{g}^{-1}\right)$ & 181.2 & 190.4 & 185.7 & \multirow[t]{2}{*}{2.014} \\
\hline Relative activity (\%) & 100 & 105.1 & 102.5 & \\
\hline Lipase (IU g ${ }^{-1}$ ) & $32.9 \mathrm{c}$ & $38.4 \mathrm{a}$ & $34.7 \mathrm{~b}$ & \multirow[t]{2}{*}{1.856} \\
\hline Relative activity (\%) & 100 & 116.7 & 105.5 & \\
\hline Trypsin $\left(\times 10^{-9} \mathrm{M} \mathrm{s}^{-1}\right)$ & $5.068 \mathrm{~b}$ & $5.833 \mathrm{a}$ & $4.988 \mathrm{~b}$ & \multirow[t]{2}{*}{0.833} \\
\hline Relative activity (\%) & 100 & 115.1 & 98.4 & \\
\hline
\end{tabular}

$\mathrm{U}$ - unit; AU - amylase unit; IU - international unit; CV - coefficient of variation. Means followed by different letters in the same row differ by SNK test $(\mathrm{P}<0.05)$. 
of $80{ }^{\circ} \mathrm{C}$. Close values were obtained by Silveira et al. (2010), who noted that pelleted diet at $75^{\circ} \mathrm{C}$ did not cause deleterious effect on the enzyme activity of the complex SSF. Moreover, Colier and Hardy (1986) verified that after the pelleting process of microbial enzymes at $70{ }^{\circ} \mathrm{C}$, the $\alpha$-amylase activity decreased its original activity by $64.5 \%$.

To all the enzymes, except for the $\alpha$-galactosidase and $\alpha$-amylase, the catalytic activity increased after the pelleting process. Probably, the moisture of the pellets favored the enzyme activity, because the presence of water is necessary for the actuation of the enzyme on a substrate, or hydrolysis.

Using the chromogenic substrate BAPNA, Marcushi (2010) also observed that the maximum trypsin activity of tambaqui (Colossoma macropomum) was verified in the $\mathrm{pH}$ range from 7.5 to 11.5 and at temperature of $70{ }^{\circ} \mathrm{C}$. As for its heat stability over time, the enzyme retained more than $60 \%$ of its initial activity after $3 \mathrm{~h}$ at $60^{\circ} \mathrm{C}$. This supports the idea that the trypsin of the present study showed greater activity during pelleting $\left(55^{\circ} \mathrm{C}\right)$, with the values reduced after the drying stage $\left(14 \mathrm{~h}\right.$ at $\left.55^{\circ} \mathrm{C}\right)$.

For the storage period, differences were not observed $(\mathrm{P}>0.05)$ for the activities of endoglucanase, sucrase, xylanase, amylase, and trypsin (Table 3). The experimental time did not influence the activities, suggesting that these enzymes remained stable during 60 days post oven. Similarly, Bedford (1996) also observed that an enzyme complex formed by amylase, protease, and xylanase withstood at $85^{\circ} \mathrm{C}$ and $90{ }^{\circ} \mathrm{C}$ during 15 and $2 \mathrm{~min}$, respectively, when subjected to the pelleting process. When stored at $22{ }^{\circ} \mathrm{C}$, the enzyme activity was maintained for 12 months.
As for the other enzymes, differences were verified $(\mathrm{P}<0.05)$ during the storage time. The $\alpha$-galactosidase and trypsin activities increased $30.8 \%$ and $2.1 \%$, respectively, while for lipase activity, a reduction of $11.8 \%$ was observed. From 15 to 60 days of storage, the endoglucanase, sucrase, xylanase, and amylase remained stable at $25^{\circ} \mathrm{C}$, because no loss of activity was observed $(\mathrm{P}>0.05)$ over time.

Among the enzymes, the $\alpha$-galactosidase presented a different standard of catalytic activity compared with other enzymes. After $14 \mathrm{~h}$ of diet drying in an oven at $55^{\circ} \mathrm{C}$, this enzyme may have suffered a partial denaturation, which reduced the activity. After a few days, the activity increased, evidencing a gradual enzyme renaturation. According to Nelson and Cox (2011), proteins (such as enzymes) can undergo a mild denaturation, with possible subsequent renaturation. Many proteins denatured by heat and other factors may regain their native structure and biological activity if returned to the previous conditions.

For trypsin, although similar activity among 15, 30, and 60 days, there was a reduction at 45 days, but still close to $100 \%$ of the initial relative activity. Under the conditions of this study, the trypsin remained near $100 \%$ relative activity throughout the trial despite some differences between treatments. In absolute values, the trypsin activity in the mixture and 60 days of storage were near $\left(5.068 \times 10^{-9} \mathrm{M} \mathrm{s}^{-1}\right.$ and $5.093 \times 10^{-9} \mathrm{M} \mathrm{s}^{-1}$, respectively).

Simulating the process of pelletizing, Ferreira et al. (2005) evaluated the lipase activity subjected to various temperatures and the presence of metallic and mineral ions in in vitro form. The authors concluded that there was loss of $16.13 \%$ activity when the lipase was subjected to $80^{\circ} \mathrm{C}$ for $15 \mathrm{~min}$. Regarding mineral solutions, all minerals and

Table 3 - Enzyme activity from enzyme complex SSF in diets for animals during the storage time at $25^{\circ} \mathrm{C}$

\begin{tabular}{|c|c|c|c|c|c|c|}
\hline \multirow{2}{*}{ Enzyme } & \multicolumn{5}{|c|}{ Sampling (days) } & \multirow{2}{*}{$\mathrm{CV}(\%)$} \\
\hline & 1 & 15 & 30 & 45 & 60 & \\
\hline Galactosidase $\left(\mathrm{U} \mathrm{g}^{-1}\right)$ & $11.02 \mathrm{c}$ & $11.45 \mathrm{c}$ & $12.32 \mathrm{bc}$ & $13.46 \mathrm{ab}$ & $14.41 \mathrm{a}$ & 5.678 \\
\hline Relative activity (\%) & 100.0 & 103.9 & 111.8 & 122.2 & 130.8 & \\
\hline Endoglucanase $\left(\mathrm{U} \mathrm{g}^{-1}\right)$ & 274.9 & 262.0 & 279.3 & 307.6 & 316.9 & 9.089 \\
\hline Relative activity (\%) & 100.0 & 95.3 & 101.6 & 111.7 & 115.3 & \\
\hline Sacarase $\left(\mathrm{U} \mathrm{g}^{-1}\right)$ & 98.90 & 98.50 & 93.95 & 77.04 & 81.90 & 11.818 \\
\hline Relative activity (\%) & 100.0 & 99.6 & 95.0 & 77.9 & 82.8 & \\
\hline Xilanase $\left(\mathrm{U} \mathrm{g}^{-1}\right)$ & 360.7 & 368.3 & 401.5 & 390.3 & 385.9 & 5.625 \\
\hline Relative activity (\%) & 100.0 & 102.1 & 111.3 & 108.2 & 107.0 & \\
\hline Amylase $\left(\mathrm{AU} \mathrm{g}^{-1}\right)$ & $185.7 \mathrm{a}$ & $186.6 \mathrm{a}$ & $180.5 b$ & $183.4 \mathrm{ab}$ & $184.0 \mathrm{ab}$ & 0.951 \\
\hline Relative activity (\%) & 100.0 & 100.5 & 97.2 & 98.8 & 99.1 & \\
\hline Lipase $\left(\mathrm{IU} \mathrm{g}^{-1}\right)$ & $34.70 \mathrm{a}$ & $33.27 \mathrm{ab}$ & $31.72 b c$ & $33.00 \mathrm{ab}$ & $30.61 \mathrm{c}$ & 2.621 \\
\hline Relative activity (\%) & 100.0 & 95.9 & 91.4 & 95.1 & 88.2 & \\
\hline Trypsin $\left(\times 10^{-9} \mathrm{M} \mathrm{s}^{-1}\right)$ & $4.988 b$ & $5.122 \mathrm{a}$ & $5.119 \mathrm{a}$ & $4.864 c$ & $5.093 \mathrm{a}$ & 0.908 \\
\hline Relative activity (\%) & 100.0 & 102.7 & 102.6 & 97.5 & 102.1 & \\
\hline
\end{tabular}

$\mathrm{U}$ - unit; AU - amylase unit; IU - international unit; CV - coefficient of variation.

Means followed by different letters in the same row differ by SNK test $(\mathrm{P}<0.05)$. 
metal ions ( $\mathrm{Ca}, \mathrm{Cu}, \mathrm{Co}, \mathrm{Mn}$, and $\mathrm{Fe})$ strongly inhibited the lipase activity in less than $42 \%$. The influence of these minerals on the lipase may explain the loss of activity in this study, because the diet was formulated with mineral supplementation, which contains all mineral and metal ions described above.

For the storage temperature of $-18^{\circ} \mathrm{C}$ (Table 4) only, no difference was observed $(\mathrm{P}>0.05)$ for endoglucanase and xylanase activities. The catalytic behavior of the enzymes during the storage time at $25^{\circ} \mathrm{C}$ were similar to enzymes subjected to $-18^{\circ} \mathrm{C}$, except for the sucrase. Normally, the enzyme activity is maintained when stored at freezing temperatures, which did not occur with this enzyme. In this case, the temperature negatively influenced $(\mathrm{P}<0.05)$ the sucrase activity with losses of $28.2 \%$ between the 1 st and the 60 th day post oven. Thus, for diets with enzyme complex SSF and high levels of sucrose, the freezing temperature should be prevented to a greater hydrolysis of the disaccharide.

The two types of storage $\left(25^{\circ} \mathrm{C}\right.$ and $\left.-18{ }^{\circ} \mathrm{C}\right)$ were compared and difference was only observed $(\mathrm{P}<0.05)$ for

Table 4 - Enzyme activity from enzyme complex SSF in diets for animals during the storage time at $-18^{\circ} \mathrm{C}$

\begin{tabular}{|c|c|c|c|c|c|c|}
\hline \multirow{2}{*}{ Enzyme } & \multicolumn{5}{|c|}{ Sampling (days) } & \multirow{2}{*}{$\mathrm{CV}(\%)$} \\
\hline & 1 & 15 & 30 & 45 & 60 & \\
\hline$\overline{\text { Galactosidase }\left(\mathrm{U} \mathrm{g}^{-1}\right)}$ & $11.02 \mathrm{~b}$ & $10.46 \mathrm{~b}$ & $12.76 \mathrm{a}$ & $12.90 \mathrm{a}$ & $12.26 \mathrm{a}$ & 4.519 \\
\hline Relative activity $(\%)$ & 100 & 94.9 & 115.9 & 117.1 & 111.3 & \\
\hline Endoglucanase $\left(\mathrm{U} \mathrm{g}^{-1}\right)$ & 274.9 & 279.4 & 320.7 & 344.7 & 323.8 & 10.813 \\
\hline Relative activity (\%) & 100 & 101.6 & 116.7 & 125.4 & 117.8 & \\
\hline Sacarase $\left(\mathrm{U} \mathrm{g}^{-1}\right)$ & $98.90 \mathrm{a}$ & $65.77 b$ & $72.69 b$ & $71.11 b$ & $71.01 \mathrm{~b}$ & 8.614 \\
\hline Relative activity (\%) & 100 & 66.5 & 73.5 & 71.9 & 71.8 & \\
\hline Xilanase $\left(\mathrm{U} \mathrm{g}^{-1}\right)$ & 360.7 & 413.4 & 393.8 & 405.8 & 376.2 & 7.014 \\
\hline Relative activity (\%) & 100 & 114.6 & 109.2 & 112.5 & 104.3 & \\
\hline Amylase $\left(\mathrm{AU} \mathrm{g}^{-1}\right)$ & $185.7 \mathrm{a}$ & $186.4 \mathrm{a}$ & $178.3 b$ & $186.3 \mathrm{a}$ & $180.7 b$ & 1.207 \\
\hline Relative activity (\%) & 100 & 100.4 & 96.0 & 100.3 & 97.3 & \\
\hline Lipase $\left(\mathrm{IU} \mathrm{g}^{-1}\right)$ & $34.70 \mathrm{a}$ & $34.60 \mathrm{a}$ & $32.10 \mathrm{c}$ & $32.86 b$ & $31.19 \mathrm{~d}$ & 1.256 \\
\hline Relative activity (\%) & 100 & 99.7 & 92.5 & 94.7 & 89.9 & \\
\hline $\operatorname{Trypsin}\left(\times 10^{-9} \mathrm{M} \mathrm{s}^{-1}\right)$ & $4.988 \mathrm{e}$ & $5.631 \mathrm{a}$ & $5.118 b$ & $5.003 \mathrm{~d}$ & $5.018 \mathrm{c}$ & 0.094 \\
\hline Relative activity (\%) & 100 & 112.9 & 102.6 & 100.3 & 100.6 & \\
\hline
\end{tabular}

$\mathrm{U}$ - unit; AU - amylase unit; IU - international unit; CV - coefficient of variation.

Means followed by different letters in the same row differ by SNK test $(\mathrm{P}<0.05)$.

Table 5 - Enzyme activity from of enzyme complex SSF in diet stocked in different temperatures

\begin{tabular}{|c|c|c|c|c|}
\hline \multirow{2}{*}{ Enzyme } & \multicolumn{4}{|c|}{ Sampling (days) } \\
\hline & 15 & 30 & 45 & 60 \\
\hline Galactosidase $25^{\circ} \mathrm{C}$ & $11.45 \mathrm{a}$ & 12.32 & 13.46 & $14.41 \mathrm{a}$ \\
\hline Galactosidase $-18^{\circ} \mathrm{C}$ & $10.46 b$ & 12.76 & 12.90 & $12.26 \mathrm{~b}$ \\
\hline CV $(\%)$ & 2.120 & 5.192 & 3.576 & 6.178 \\
\hline Endoglucanase $25^{\circ} \mathrm{C}$ & 262.0 & 279.3 & 307.6 & 316.9 \\
\hline Endoglucanase $-18^{\circ} \mathrm{C}$ & 279.4 & 320.7 & 344.7 & 323.8 \\
\hline $\mathrm{CV}(\%)$ & 7.653 & 13.586 & 5.964 & 12.222 \\
\hline Sacarase $25^{\circ} \mathrm{C}$ & $98.50 \mathrm{a}$ & 93.95 & 77.04 & 81.90 \\
\hline Sacarase $-18^{\circ} \mathrm{C}$ & $65.77 b$ & 72.69 & 71.11 & 71.01 \\
\hline CV $(\%)$ & 8.667 & 15.339 & 7.036 & 15.153 \\
\hline Xylanase $25^{\circ} \mathrm{C}$ & $368.3 \mathrm{a}$ & 401.5 & 390.5 & 385.9 \\
\hline Xylanase $-18^{\circ} \mathrm{C}$ & $413.4 b$ & 393.8 & 405.8 & 376.2 \\
\hline CV $(\%)$ & 2.726 & 3.619 & 10.520 & 5.989 \\
\hline Amylase $25^{\circ} \mathrm{C}$ & 186.6 & 180.5 & 183.4 & 184.0 \\
\hline Amylase $-18^{\circ} \mathrm{C}$ & 186.4 & 178.3 & 186.3 & 180.7 \\
\hline CV $(\%)$ & 0.848 & 1.267 & 1.454 & 1.103 \\
\hline Lipase $25^{\circ} \mathrm{C}$ & $33.27 \mathrm{a}$ & 31.72 & 33.00 & 30.61 \\
\hline Lipase $-18^{\circ} \mathrm{C}$ & $34.60 \mathrm{~b}$ & 32.10 & 32.86 & 31.19 \\
\hline $\mathrm{CV}(\%)$ & 0.842 & 1.731 & 3.266 & 2.669 \\
\hline Trypsin $25^{\circ} \mathrm{C}$ & $5.122 \mathrm{a}$ & 5.119 & 4.864 & $5.093 \mathrm{a}$ \\
\hline Trypsin $-18^{\circ} \mathrm{C}$ & $5.631 b$ & 5.118 & 5.003 & $5.018 b$ \\
\hline $\mathrm{CV}(\%)$ & 0.306 & 0.090 & 1.427 & 0.112 \\
\hline
\end{tabular}

$\mathrm{CV}$ - coefficient of variation.

Means followed by different letters differ by $\mathrm{F}$ test $(\mathrm{P}<0.05)$. 
galactosidase and trypsin activities at 60 days (Table 5). At temperature of $25^{\circ} \mathrm{C}$, these enzymes showed higher activity than those subjected to temperature of $-18{ }^{\circ} \mathrm{C}$, however, both superior than the initial activity. For all enzymes from complex SSF, no significant difference $(\mathrm{P}>0.05)$ between 30 and 45 days was verified.

This result indicated that pelleted diet containing enzyme complex SSF does not need to be kept in negative temperatures up to 60 days, because the form of protection for this product provides stability to the processing and storage. This is advantageous for companies and producers, since it reduces the costs for obtaining cold storage and energy.

\section{Conclusions}

The enzymes evaluated from the enzyme complex SSF do not lose the stability when subjected to processing of pelleted diet at $55{ }^{\circ} \mathrm{C}$, maintaining the activity for at least 60 days when stored in temperature at up to $25^{\circ} \mathrm{C}$.

Diets containing the enzyme complex SSF do not need to be maintained at negative temperatures down to $-18^{\circ} \mathrm{C}$.

The enzyme complex SSF should be evaluated at higher processing temperatures and storage time greater than 60 days.

\section{Acknowledgments}

We would like to thank CNPq, CAPES, FAPEMIG, and Alltech Inc. for financial support.

\section{References}

Bedford, M. R. 1996. The effect of enzymes on digestion. Journal Applied Poultry Research 5:370-378.

Caraway, W. T. 1959. A stable starch substrate for the determination of amylase in serum and other body fluids. American Journal of Clinical Pathology 32:97-99.

Cherry, I. S. and Crandall, L. A. 1932. The specificity of pancreatic lipase: it's appearance in the blood after pancreatic injury. American Journal of Physiology 100:266.

Colier, B. and Hardy, B. 1986. The use of enzymes in the pig and poultry feeds. Feed Compounder 6:14-19.

Cowan, W. D. 1993. Understanding the manufacturing, distribuition, application and overall quality of enzymes in poultry feeds. Journal Applied Poultry Research 2:93-95.

Dias, J. C. C. A.; Santiago, G. S.; Ferreira, W. M. and Saliba, E. O. S. 2002. Avaliação da estabilidade in vitro de uma protease comercial. Arquivo Brasileiro de Medicina Veterinária e Zootecnia 54:618-622.

Erlanger, B. F.; Kokowsky, N. and Chen, N. 1961. The preparation and properties of two new chromogenic substrates of trypsin. Archives of Biochemistry and Biophysics 95:271-278.

Ferreira, V. P. A.; Ferreira, W. M.; Saliba, E. O. S. and Teixeira, A. O. 2005. Reatividade in vitro de lipase submetida a diferentes tratamentos tecnológicos. Arquivo Brasileiro de Medicina Veterinária e Zootecnia 57:340-344.

Finnfeeds Internacional. 1991. Enzymes in animal nutrition. Technical Support Manual, England.

Francesch, M.; Pérez-Vendrell, A. M.; Esteve-García, E. and Brufau, J. 1995. Enzyme supplementation of a barley and sunflower-based diet on laying hen performance. Journal Applied Poultry Research 4:32-40.

Leite, P. R. S. C.; Leandro, N. S. M.; Stringhine, J. H.; Café, M. B.; Gomes, N. A. and Jardim Filho, R. M. 2011. Desempenho de frangos de corte e digestibilidade de rações com sorgo ou milheto e complexo enzimático. Pesquisa Agropecuária Brasileira 46:280-286.

Marcushi, M. 2010. Purificação e caracterização de uma tripsina do peixe amazônico tambaqui (Colossoma macropomum). Dissertação (M.Sc.). Universidade Federal de Pernambuco, Recife, PE, Brazil.

Miller, G. L. 1956. Use of dinitrosalicylic acid reagent for determination of reducing sugar. Analytical Chemistry 31:426-428.

Moura, G. S.; Pedreira, M. M.; Lanna, E. A. T.; Santos, A. E.; Ferreira, T. A.; Pires, A. V. 2015. Crambe meal in diets supplemented with enzyme complex SSF (solid state fermentation) for Nile tilapia. African Journal of Agricultural Research 10:289-294.

Nelson, D. L. and Cox, M. M. 2011. Lehninger princípios de bioquímica. 5.ed. Artmed - Sarvier, Porto Alegre.

Opalinski, M.; Maiorka, A.; Cunha, F.; Rocha, C. and Borges, S. A. 2010. Adição de complexo enzimático e da granulometria da soja integral desativada sobre o desempenho de frangos de corte. Ciência Rural 40:628-632.

Ramos, G. D. M.; Ascheri, J. R.; Silva, L. G.; Damaso, M. C. T.; Souza, G. F. and Couri, S. 2012. Estabilidade da fitase de Aspergillus Níger 11T53A9 ao armazenamento e sua aplicação na hidrólise do ácido fítico na farinha de sorgo. Revista Brasileira de Agrociência 18:95-106.

Rostagno, H. S.; Albino, L. F. T.; Donzele, J. L.; Gomes, P. C.; Oliveira, R. F.; Lopes, D. C.; Ferreira, A. S.; Barreto, S. L. T. and Euclides, R. F. 2011. Brazilian tables for poultry and swine: composition of feedstuffs and nutritional requeriments. 3rd ed. UFV, Animal Science Department, Viçosa, MG.

Silveira, M. H. D.; Usso, J. T. Z.; Rossi, P.; Rutz, F.; Anciuti, M. A.; Zauk, N. F.; Ribeiro, C. L. G.; Brum, P. A. R. and Nunes, J. K. 2010. Efeito da peletização em dietas contendo complexo enzimático para frangos de corte. Ciência Animal Brasileira 11:326-333.

Shah, A. R. and Madamwar, D. 2005. Xylanase production by a newly isolated Aspergillus foetidus strain and its characterization. Process Biochemistry 40:1763-177.

Spring, P.; Newman, K. E.; Wenk, V.; Messikommer, R. and Vukicvranjes, M. 1996. Effect of pelleting temperature on the activity of different enzymes. Poultry Science 75:357-361.

Vats, P. and Banerjee, U. C. 2004. Production studies and catalytic properties of phytases (myo-inositolhexakisphosphate phosphohydrolases): an overview. Enzyme and Microbial Technology 35:3-14. 